\title{
Desmoplastic small round cell tumor of the kidney: a case report
}

Dilek Ertoy Baydar ${ }^{1 *+}$ (D) Ayse Armutlu+ ${ }^{1 \dagger}$ Oguz Aydin², Ayhan Dagdemir ${ }^{3}$ and Yarkin Kamil Yakupoglu ${ }^{4}$

\begin{abstract}
Background: Desmoplastic small round cell tumor (DSRCT) is a rare, aggressive neoplasm seen in children and young adults, usually manifested by involvement of abdominal serosa. Here, we present an unusual case of primary DSRCT of kidney.

Case presentation: The patient was an 8-year-old girl with a large renal mass which was confused with primitive neuroectodermal tumor (PNET) in the needle biopsy. The tumor had a variegated histology revealing frequent pseudo-rosette formations, pseudopapillary architecture, rhabdoid, clear or pleomorphic cells in addition to typical small round cell morphology and desmoplasia. It showed immunohistochemical features of DSRCT, and EWSR1 rearrangement.

Conclusions: Proffering this diagnosis is particularly difficult for tumors of viscera because of the incognizance of the entity in these locations. Moreover, DSRCT is a great mimicker and may get easily confused with more common kidney malignancies of childhood such as Wilms tumor, PNET/EWS, rhabdoid tumor, clear cell sarcoma, and other small round cell tumors as well as renal cell carcinomas. The distinction is critical as the accurate therapeutic approach will require correct diagnosis.
\end{abstract}

Keywords: Desmoplastic small round cell tumor, Kidney, WT1, EWSR1, Case report

\section{Background}

Desmoplastic small round cell tumor (DSRCT) is a rare, distinct entity that was first described by Gerald and Rosai in 1989 [1]. Predilection for adolescent males, predominant intraabdominal location involving serosal surfaces, nesting pattern of growth, focal rhabdoid morphology, prominent desmoplastic reaction, immunohistochemical reactivity for epithelial, neural and muscle markers, and highly aggressive clinical behavior are its main features. DSRCT shows a specific reciprocal chromosomal translocation, $\mathrm{t}(11 ; 22)(\mathrm{p} 13 ; \mathrm{q} 12)$ (EWSR1WT1 fusion) which generates a chimerical protein with transcriptional regulatory activity. Extraserosal DSRCTs

\footnotetext{
* Correspondence: dertoy@kuh.ku.edu.tr; dilekertoy@yahoo.com

${ }^{\dagger}$ Dilek Ertoy Baydar and Ayse Armutlu contributed equally to this work.

'Department of Pathology, Koc University School of Medicine, Topkapi, 34010 Istanbul, Turkey

Full list of author information is available at the end of the article
}

are extremely rare with only a few cases reported in lungs, ovary, soft tissues, bones, intracranial and sinonasal locations $[2,3]$.

DSRCT primary of the kidney was first described by $\mathrm{Su}$, et al. [4] in 2004 and since then only a total of 12 cases have been reported in the literature (Table 1) [5-12]. Herein, we present the thirteenth case of renal DSRCT that had variant histological features mimicking various types of other neoplasia. The pathologic diagnosis of this entity can be markedly challenging when it develops in visceral organs such as kidney and especially if diverse and confounding microscopic features are present.

\section{Case presentation \\ Clinical history}

An 8-year-old girl complained of abdominal pain and an ultrasonography found a large mass in her left kidney.

(c) The Author(s). 2020 Open Access This article is licensed under a Creative Commons Attribution 4.0 International License, which permits use, sharing, adaptation, distribution and reproduction in any medium or format, as long as you give appropriate credit to the original author(s) and the source, provide a link to the Creative Commons licence, and indicate if changes were made. The images or other third party material in this article are included in the article's Creative Commons licence, unless indicated otherwise in a credit line to the material. If material is not included in the article's Creative Commons licence and your intended use is not permitted by statutory regulation or exceeds the permitted use, you will need to obtain permission directly from the copyright holder. To view a copy of this licence, visit http://creativecommons.org/licenses/by/4.0/ The Creative Commons Public Domain Dedication waiver (http://creativecommons.org/publicdomain/zero/1.0/) applies to the data made available in this article, unless otherwise stated in a credit line to the data. 


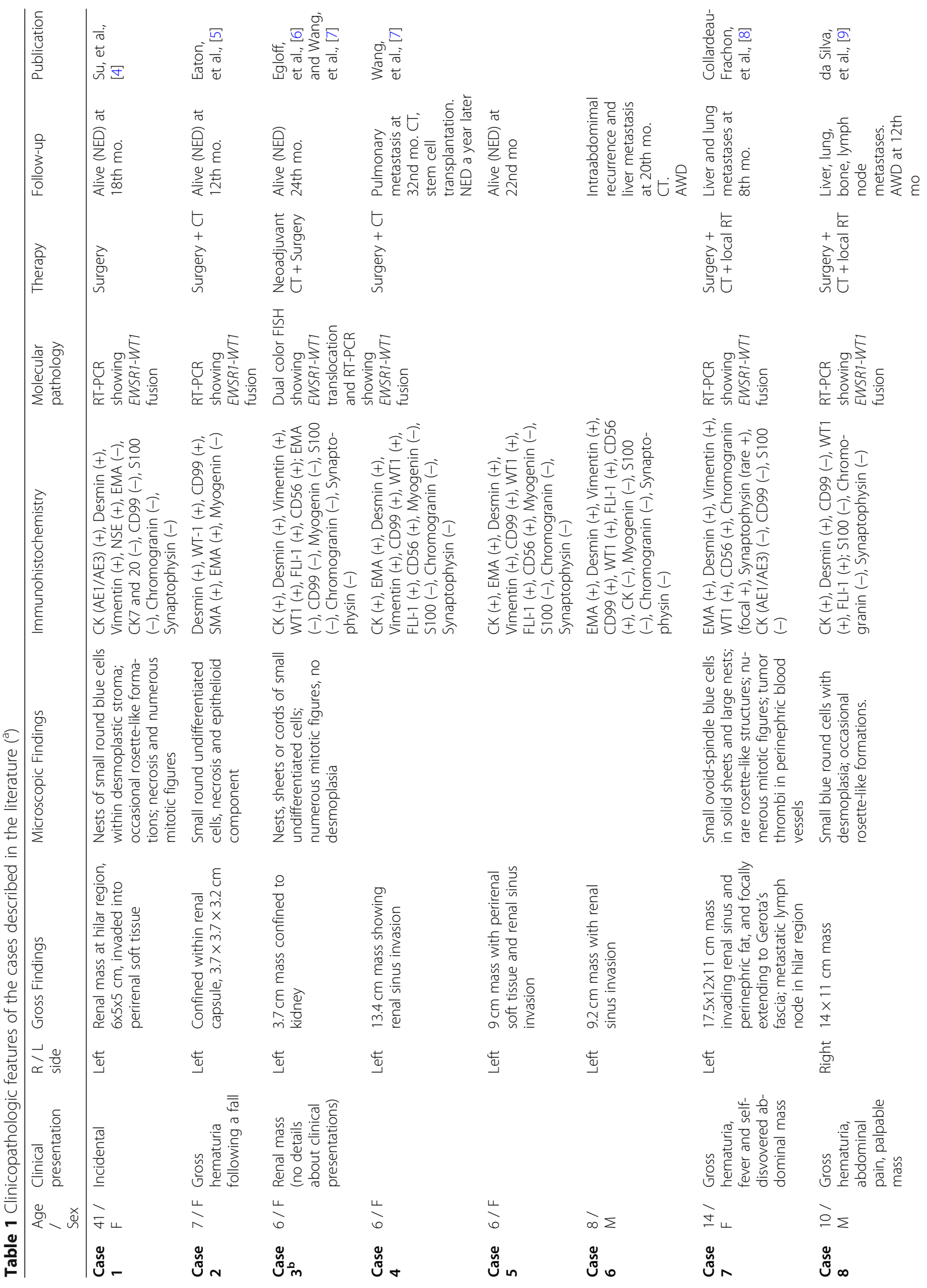




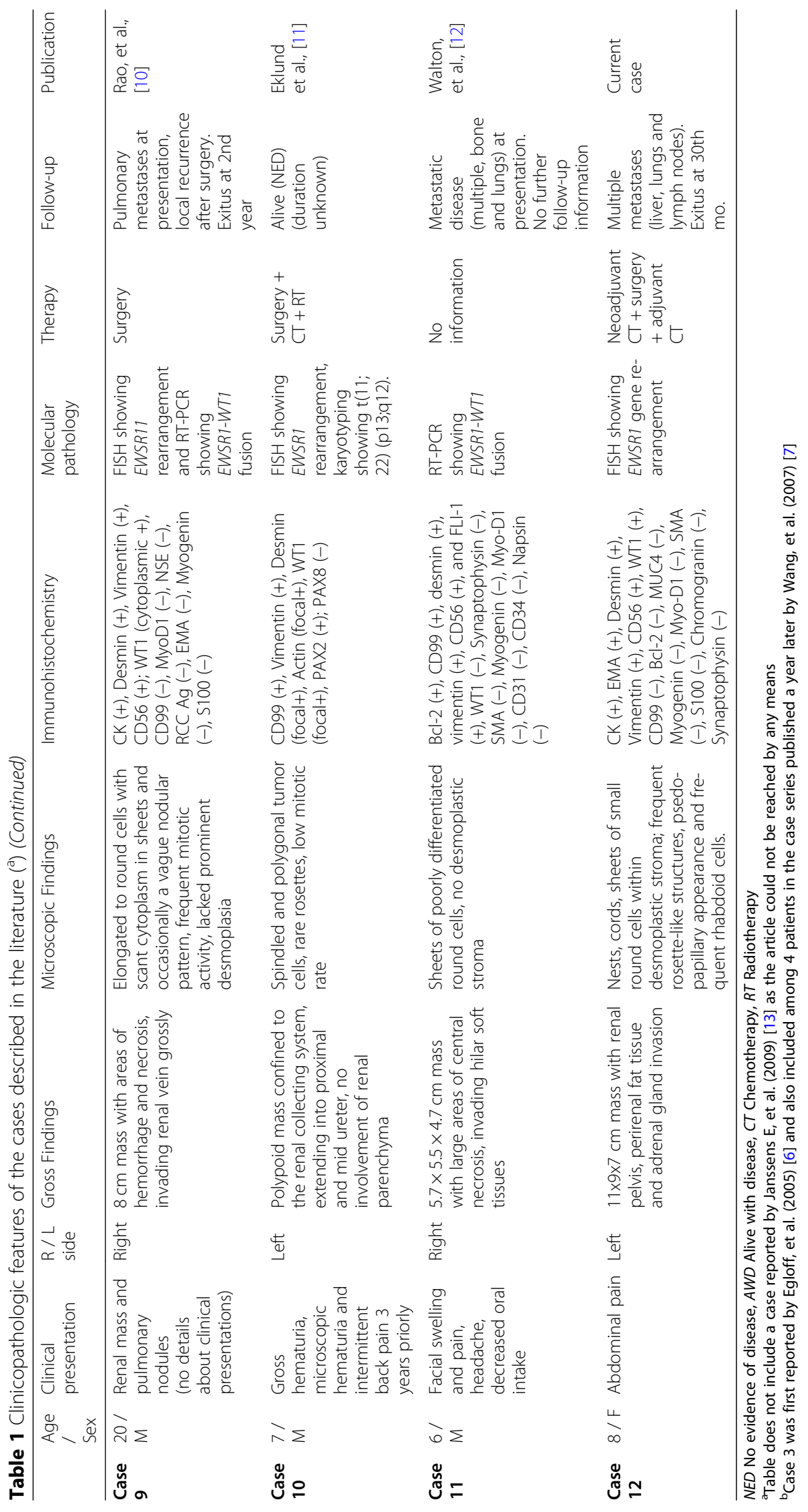


Abdomimal MRI showed that it was a heterogenous lobulated solid lesion measuring $80 \times 92 \times 118 \mathrm{~mm}$ in size with cystic and necrotic areas. Needle biopsy from the tumor was diagnosed in an outside center as a small round blue cell tumor consistent with PNET/EWS. The patient had multiple lung, liver, adrenal and lymph node metastases at initial presentation. After 6 cycles of neoadjuvant chemotherapy, left radical nephrectomy was performed. Macroscopic examination showed 11x9x7 cm grey-white solid mass that occupied most of the organ parenchyma, invading also renal pelvis, perirenal soft tissue and adrenal gland extensively. Paraffin blocks of both needle biopsy and nephrectomy material were sent to our institution for consultation.

\section{Pathology}

On histopathologic examination, neoplastic cells formed nests, cords and sheets within desmoplastic stroma (Fig. 1). Tumor also revealed intermittent areas of primitive tubule or rosette-like structures (Fig. 2). Furthermore, occasional foci appeared to have (psedo) papillary architecture with foamy histiocytes which was possibly due to drop-outs and loss of cohesion between cells (Fig. 3). Most neoplastic cells were small with narrow cytoplasm and round monotonous hyperchromatic nuclei. However, there were areas that contained unusually large amounts of eosinophilic, clear or vacuolated cytoplasm. Some cells revealed rhabdoid features, or pleomorphic, even multilobated nuclei (Fig. 4). Immunohistochemically, neoplasm diffusely expressed EMA,

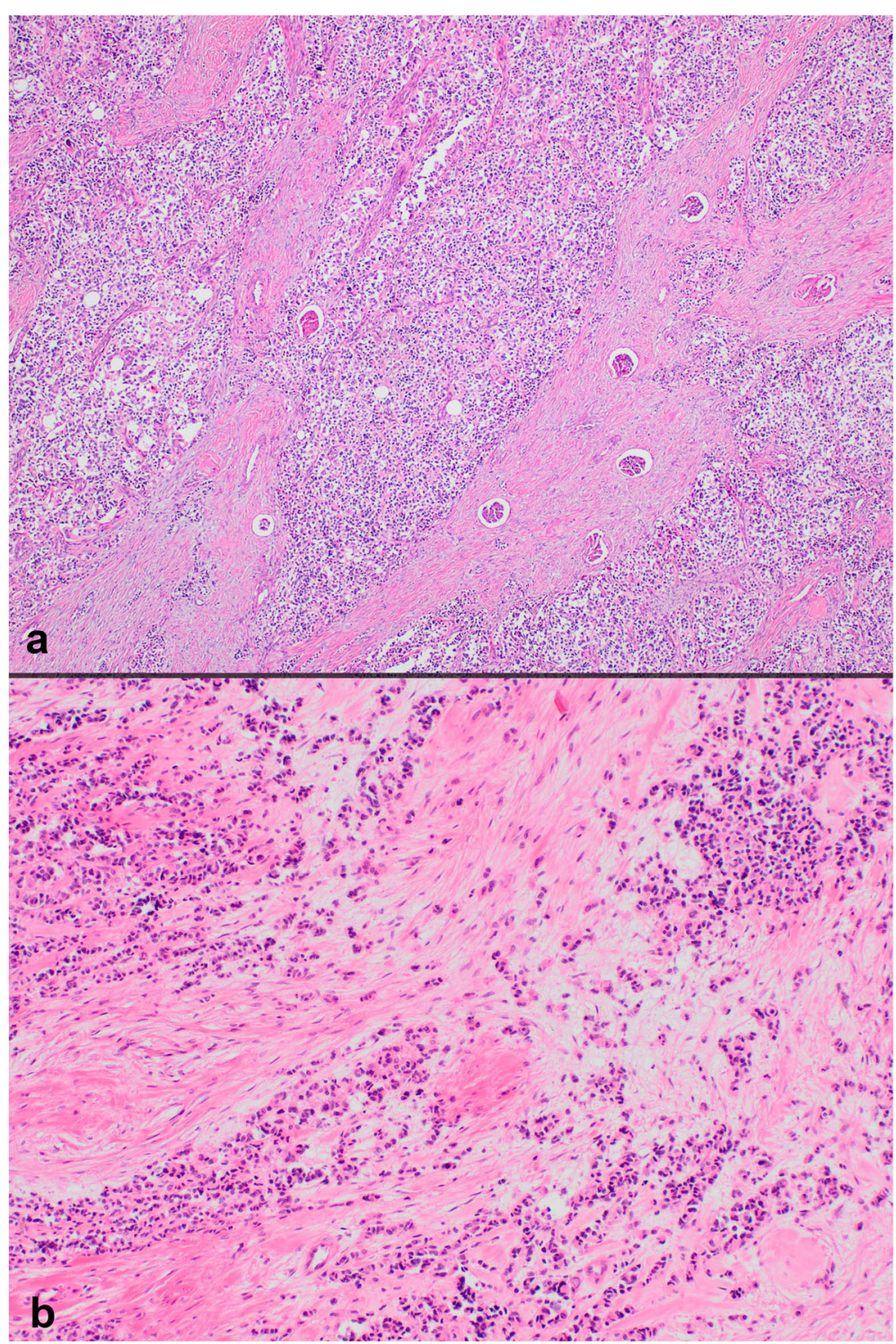

Fig. 1 Sheets, nests and cords of neoplastic cells in a desmoplastic stroma (a H\&E $\times 40$; b H\&E $\times 100$ ) 


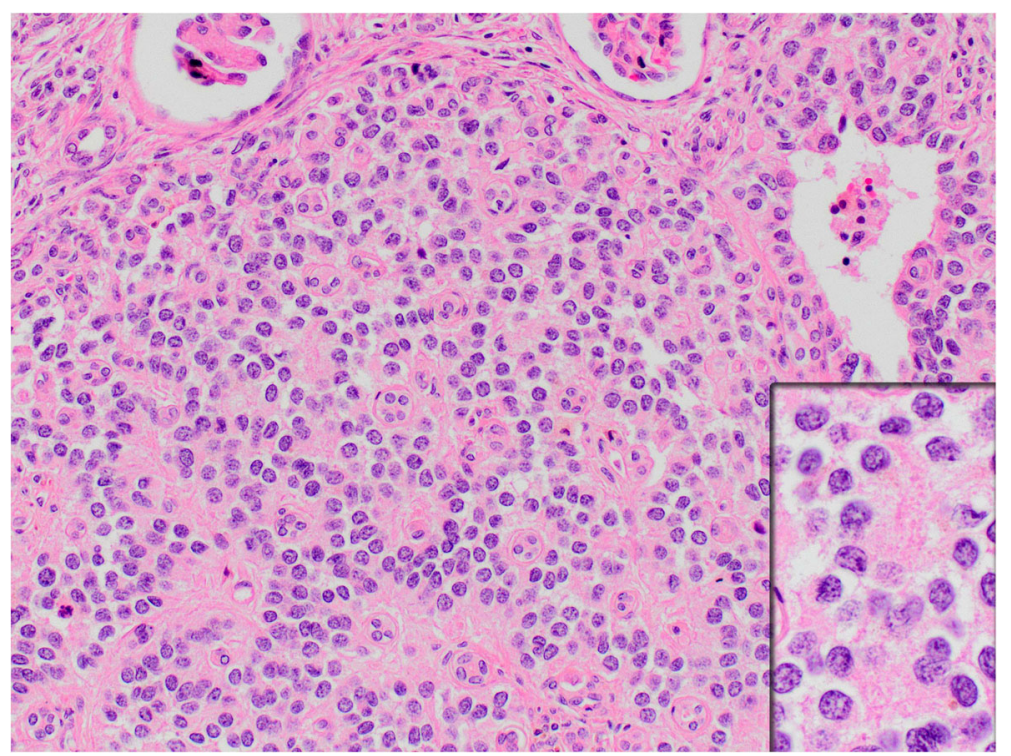

Fig. 2 Rosette or tubule-like formations (H\&E $\times 200$; inset: $H \& E \times 400)$

pan-cytokeratin, CD56, vimentin and desmin (paranuclear dot-like) whereas it stained negative for synaptophysin, chromogranin, S100, CD99, bcl-2, myo-D1, GATA3 and PAX8 (Fig. 5a-b). Nuclear INI1 was intact. Antibodies directed to $\mathrm{N}$-terminus of WT1 protein stained cytoplasm of the tumor cells non-specifically without nuclear immunoreactivity (Fig. 5c). FISH analysis with a break-apart probe proved EWSR1 gene re-arrangement in the neoplastic cells (Fig. 5d). Our final diagnosis was desmoplastic small round cell tumor of the kidney.

\section{Follow-up}

The child was given multiple cycles and different combinations of adjuvant chemotherapy. She had a local relapse in the 2nd year that underwent salvage resection. Chemotherapy was continued thereafter, but she died in the 30th month from her first operation due to disease progression and wide-spread metastases.

Informed consent was obtained from the parents of the deceased child for the publication of the patient information and microscopic images.

\section{Discussion and conclusions}

DSRCT is a rare, aggressive sarcoma placed in the family of small round cell tumors, typically seen in children and young adults with a male predilection. The disease most commonly originates in the abdominal or pelvic serosa. Primary DSRCT in extraserosal sites is extremely unusual. Classical histology of DSCRT is the nesting pattern of small round to oval cells separated by prominent desmoplastic stroma, focal rhabdoid features, and immunohistochemical profile with peculiar coexpression of epithelial (EMA and keratin), neural (NSE) and mesenchymal (vimentin and desmin) markers. The cytogenetics of a case of DSRCT, featuring a diploid DNA content and $t(11 ; 22)(\mathrm{p} 13 ; \mathrm{q} 12)$ was first reported in 1992 by Sawyer JR, et al. [14] In1994, Ladanyi and Gerald defined the consistent fusion between EWSR1 and WT1 genes in DSRCTs [15]. In a publication in 1995, they proved that DSRCT represents the third tumor type associated with EWSR1 translocation, and it is the only malignancy holding EWSR1 - WT1 rearrangement [16].

Urogenital DSRCT may involve bladder, ureters, prostate and paratesticular structures [17]. Primary DSRCT of the kidney was first noted by Su, et al. [4] in 2004 and 12 cases have been reported in the literature thereafter [5-12] albeit one of them has an inaccessible publication. Although male predilection is emphasized in abdominal DSRCTs, most of renal cases including ours have been female $(F / M=7 / 5)$. Majority were detected incidentally or presented with gross hematuria and/or abdominal pain. Most tumors had infiltrative appearance with a size ranging from 3.7 to $17.5 \mathrm{~cm}$ in diameter. Two cases were confined to kidney [5, 7] and one case was limited to the renal collecting system without parenchymal involvement [12]. Interestingly, 9 out of 12 renal DSRCTs preferred left kidney.

DSRCTs may manifest unusual histologies such as tubule or rosette-like structures, papillary formations, abundant rhabdoid cells, predominantly spindle cell morphology, ample clear cytoplasm and absence of significant desmoplasia. The recognition of the morphologic diversity is important to avoid a misinterpretation during pathologic diagnosis especially when tumors are located in unusual sites. DSRCT of kidney appears to be 


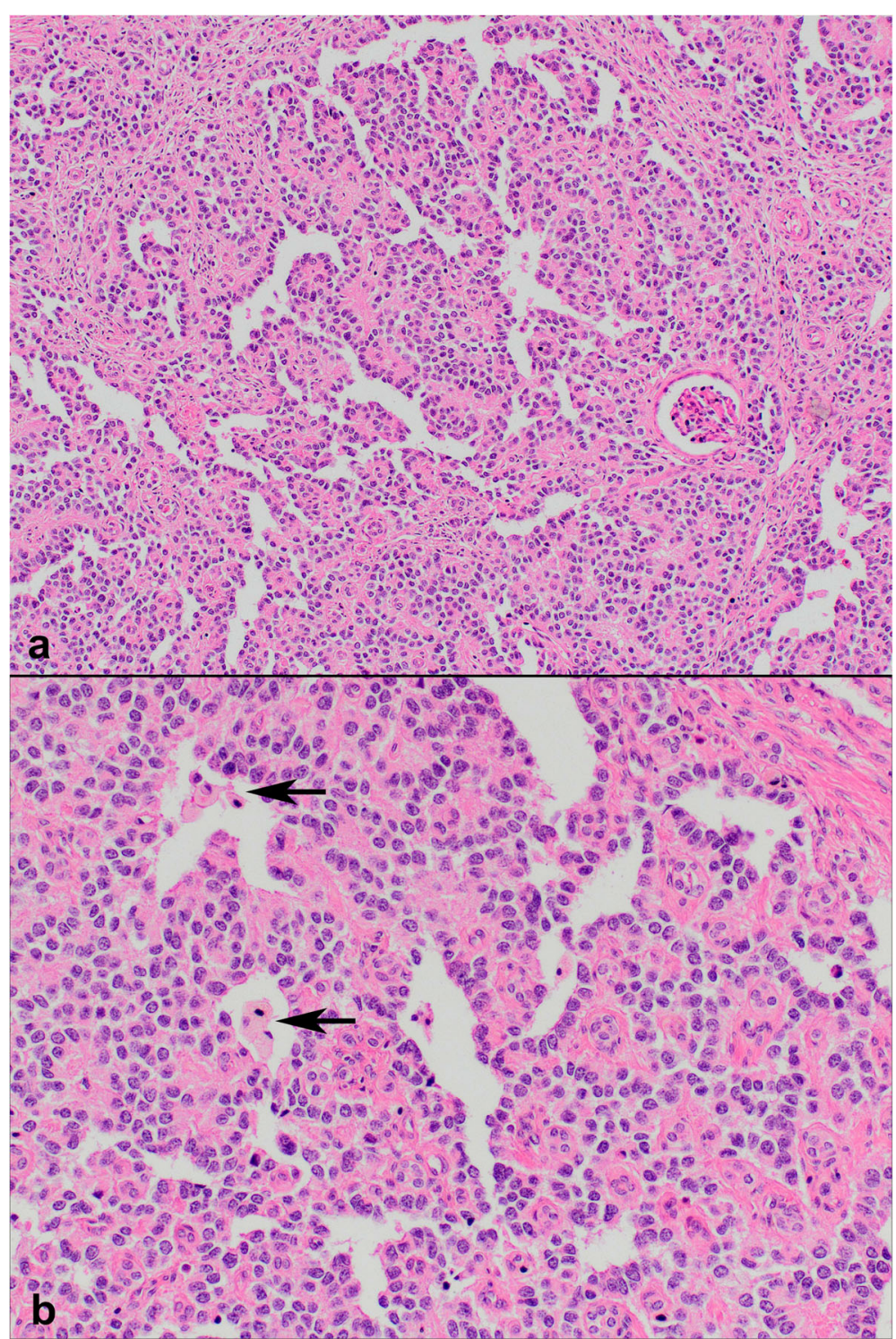

Fig. 3 Pseudo-papillary pattern with foamy histiocytes (arrows) (a H\&E $\times 100 ;$ b H\&E $\times 200$ )

a childhood neoplasm as almost all cases were pediatric, 6 to 8 years being the most frequent, with only two adult patients. Given this and also overlapping histopathologic features, main differential diagnosis of DSRCT is Wilms tumor (WT) in the kidney, the most common renal malignancy of children. Although the peak incidence of Wilms tumor is between 2 and 3 years, it can occasionally occur at later ages. Blastemal-predominant WT can be challenging to distinguish histologically from DSRCT and pseudo-rosette or tubule-like arrangements in DSRCT may mimic epithelioid component of WT. DSRCT localized to the kidney can lack desmoplastic reaction or WT can demonstrate desmoplasia. Both tumors show nuclear positivity immunohistochemically with antibodies against carboxy terminus of WT1 protein. Yet, immunohistochemistry is still useful in the discrimination: While WT is characterized by dual nuclear immunoreactivity for both amino- and carboxy-terminus WT1 antibodies, neoplastic nuclei in DSRCT do not stain with antibody recognizing amino-terminal of WT1 although non-specific cytoplasmic positivity can be seen as in our case. This can be explained by the fusion of the EWSR1 gene to the last three exons (carboxyterminus) of WT1 in DSRCT. The re-arrangement produces a protein containing the zinc finger region of WT1 which needs C-terminal antibodies for recognition. It has been shown that blastemal WT may express paranuclear desmin in $50 \%$ of cases [18], however this is 


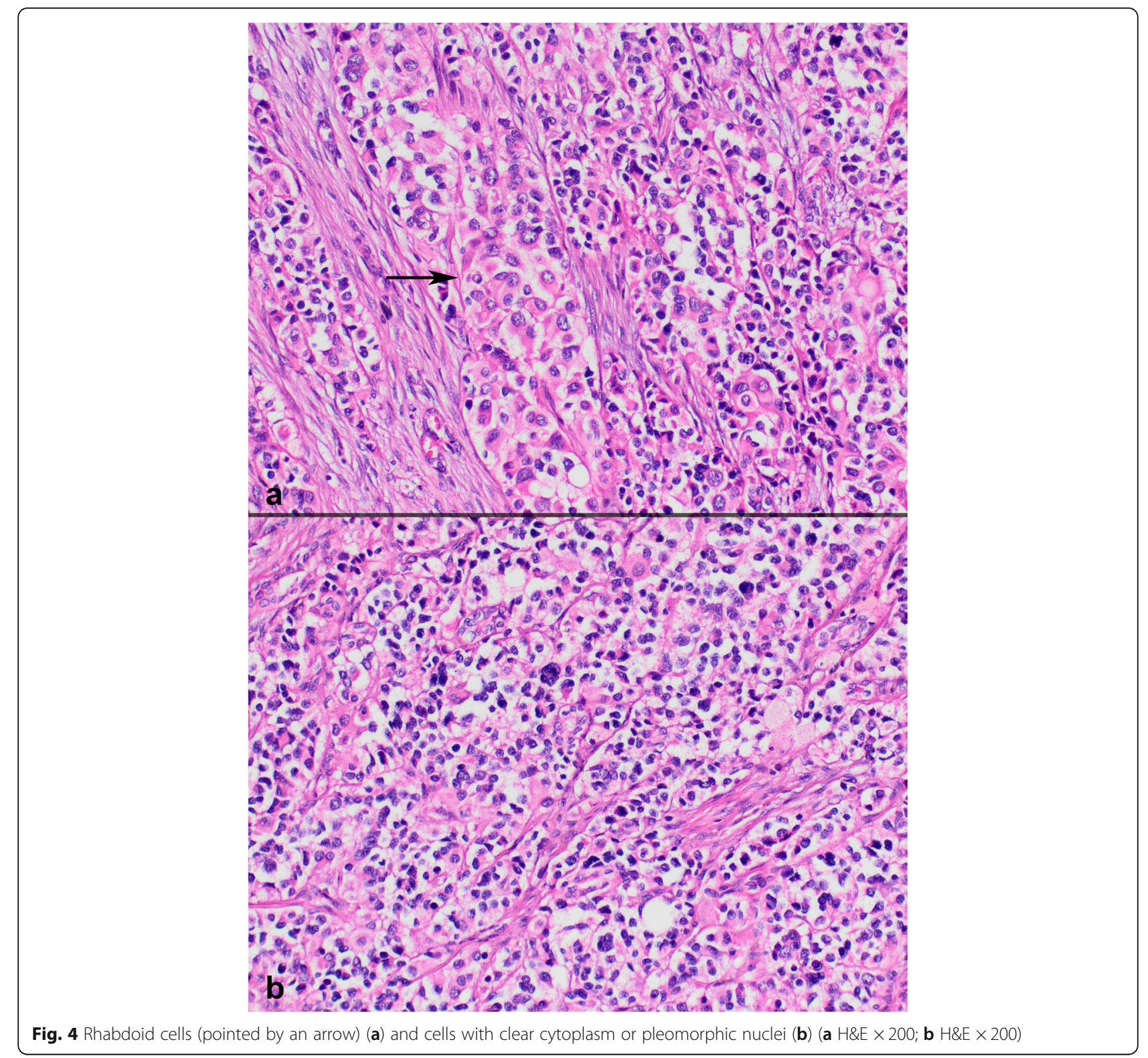

usually not widespread. Extensive (> 75\%) paranuclear dotlike desmin positivity in addition to negative PAX8 and bland nuclear features will suggest DSRCT [18].

Other pediatric renal tumors, clear cell sarcoma and rhabdoid tumor, may also need to excluded from DSRC $\mathrm{T}$ in the kidney although these two preferentially occur in infancy or at very early childhood. DSRCT lacks capillary network of clear cell sarcoma and large nucleolus or prominent cytoplasmic inclusions of rhabdoid tumor. It has intact nuclear INI1 protein expression contrary to rhabdoid tumor. Clear cell sarcomas are negative for epithelial and muscle markers, and they have recently been shown to overexpress nuclear BCOR protein $[19,20]$.

DSRCT may mimic PNET/EWS, especially when it has a solid growth pattern. PNET/EWS was the first diagnosis in our patient, given to the needle biopsy taken from the mass, which was mainly suggested by the presence of frequent pseudorosettes in the tumor. These two different tumor types have similar age distribution, similar cytology and both harbor EWSR1 rearrangements. Keratin expression may be seen nearly in $25 \%$ of Ewing sarcomas, but desmin positivity is exceedingly rare and keratin plus desmin coexpressing Ewing sarcoma has not been asserted. DSRCTs show more variable expression of CD99, rather than the diffuse membranous positivity typical of Ewing sarcoma. The characteristic translocation of Ewing sarcoma involves EWSR1 and the ETS family of transcription factors, not WT1, and it lacks nuclear WT1 expression. The break-apart FISH assay for EWSR1 will not be helpful in the differential 


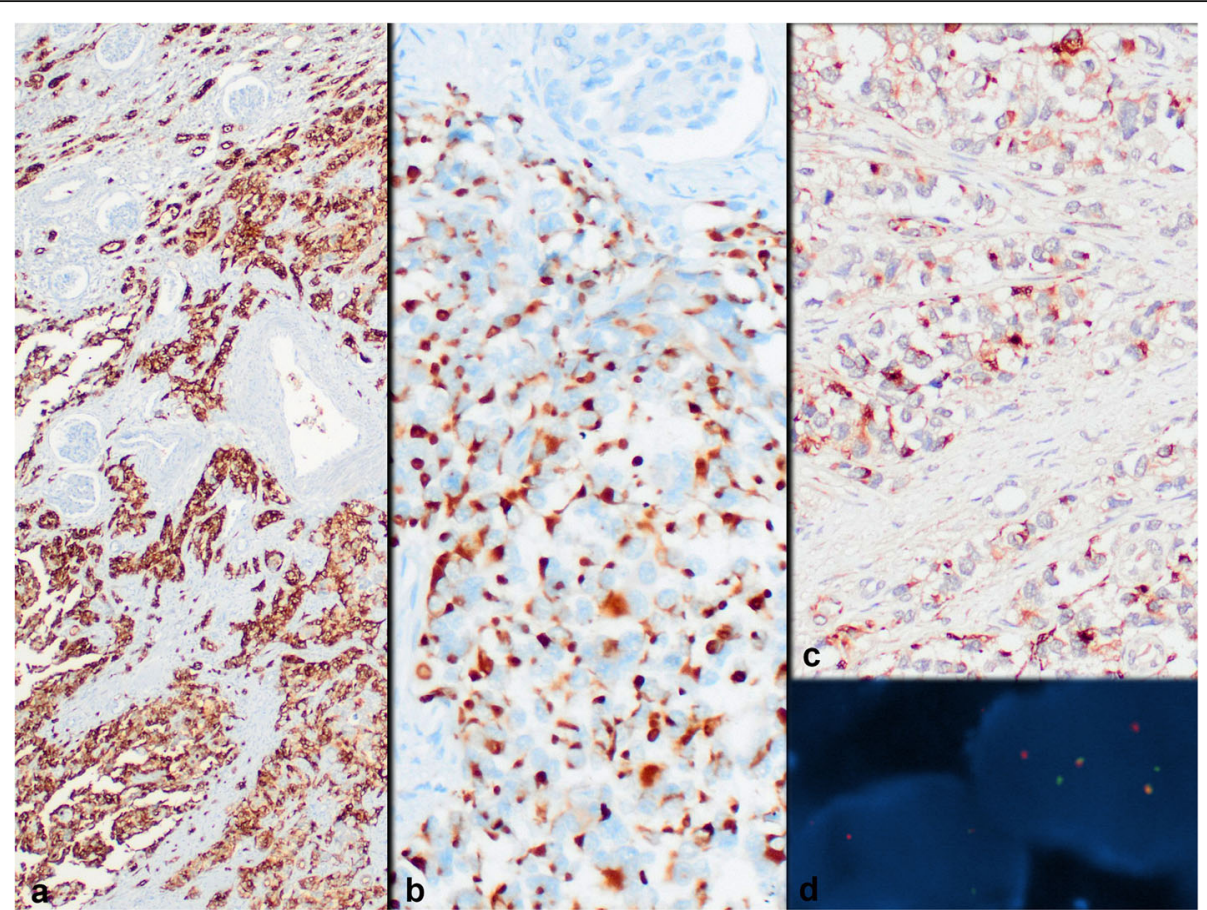

Fig. 5 Strong EMA (a), perinuclear dot-like desmin (b) and non-specific cytoplasmic (non-nuclear) WT1 expression (c) by neoplastic cells, (d) is FISH analysis showing ESWR1 rearrangement (a Immunohistochemistry, anti-EMA Ab $\times 40 ; \mathbf{b}$ Immunohistochemistry, anti-desmin Ab $\times 200 ; \mathbf{c}$ Immunohistochemistry, anti-WT1 (N-terminal) Ab $\times 200$; d Dual Color Break Apart specific locus FISH probe targeting EWSR1 gene at 22 q12.2 chromosomal region; green and red signals mark the $5^{\prime}$ and $3^{\prime}$ ends of the gene respectively)

diagnosis between DSRCT and PNET/EWS as one fusion partner in both tumors is this same gene. Given the previous reports of a few curious cases carrying hybrid features of both DSRCT and PNET/EWS but with EWSR1-FLI1 or EWSR1-ERG fusion [21, 22], the gold standard for the definitive diagnosis of DSRCT would be demonstration of the EWSR1-WT1 fusion by RT-PCR when feasible. It was not possible in our case due to low quality of extracted RNA from paraffin block.

Lymphoma/leukemia, metastatic neuroblastoma, poorly differentiated synovial sarcoma and rhabdomyosarcoma are the other tumors that need to be considered in the differential diagnosis of renal DSRCT. Lymphoma/leukemia often demonstrate a diffuse growth pattern and do not exhibit the cohesion and nuclear features of DSRCT, and can be excluded by a panel of lymphoid markers or TdT. Neuroblastoma occurs in very young children, over $90 \%$ being diagnosed below 5 years of age. Clinical and laboratory evaluation will usually reveal an adrenal mass and elevated catecholamine metabolites in urine. Neuroblastoma lacks the specific chromosomal translocation and all show HISL-19 expression. Synovial sarcoma characteristically harbors SYT-SSX gene fusion ( $t(X ; 18)(p 11 ; q 11))$. Rhabdomyosarcoma generally does not have a desmoplastic stroma and unlike DSRCT, it will express myogenin and MyoD1, and the majority of alveolar rhabdomyosarcoma have FOXO1 fusions.

In our case, there were areas of cellular discohesion with groups of foamy histiocytes, leading to focal pseudopapillary architecture and bringing papillary type renal cell carcinoma (RCC) into consideration. Additionally, we have observed some small nests consisted of neoplastic cells with clear cytoplasm, reminiscent of clear cell RCC. Strong cytokeratin and EMA expression might favor an epithelial neoplasm, however negative immunoreactivity for PAX8 turned us away from the renal cell origin in the first round.

DSRCT is known to have a poor prognosis. Our patient who presented with multiple distant metastases at the initial diagnosis died at the 30th month despite radical operation and intensive chemotherapy. However, the detection of the disease at early stage and complete resectability may provide significant prognostic benefit as previously reported: 6 out of 11 renal DSRCTs were stated alive without disease, keeping in mind that the follow-up durations are too short to drive a reliable conclusion. The best therapeutic modality has yet to be explored for renal DSRCT. A combination of total resection and chemotherapy seems to be the most preferred strategy at the moment. 
As a conclusion, DSRCT is a rare disease, but should be considered in the differential diagnosis of small round cell tumors of the kidney in pediatric patients. This is important as each one of those tumors has different clinical behavior, prognosis, and treatment implications. Immunohistochemical and molecular studies have particular guidance for the right analytic approach, and documentation of EWSR1-WT1 fusion is the "gold standard" for the diagnosis of DSRCT as it appears exceedingly characteristic for this disease.

\section{Abbreviations}

DSRCT: Desmoplastic small round cell tumor; PNET: Primitive neuroectodermal tumor; EWS: Ewing sarcoma; WT: Wilms tumor; RTPCR: Reverse transcription polymerase chain reaction

\section{Acknowledgements}

Not applicable.

\section{Authors' contributions}

The report was designed, written, and reviewed by DEB and AA. All authors contributed to the data collection, data analysis, and interpretation. The manuscript was approved by all authors.

\section{Funding}

None.

\section{Availability of data and materials}

Stained and unstained slides of the case can be provided if required.

\section{Consent for publication}

Informed consent was obtained from the parents of the deceased child.

\section{Competing interests}

The authors declare that they have no competing interests.

\section{Author details}

'Department of Pathology, Koc University School of Medicine, Topkapi, 34010 Istanbul, Turkey. ${ }^{2}$ Department of Pathology, Ondokuz Mayis University School of Medicine, Samsun, Turkey. ${ }^{3}$ Department of Pediatric Oncology, Ondokuz Mayis University School of Medicine, Samsun, Turkey. ${ }^{4}$ Department of Urology, Ondokuz Mayis University School of Medicine, Samsun, Turkey.

Received: 21 April 2020 Accepted: 14 July 2020

Published online: 23 July 2020

\section{References}

1. Gerald WL, Rosai J. Case 2. Desmoplastic small cell tumor with divergent differentiation. Pediatr Pathol. 1989;9:177-83.

2. Syed S, Haque AK, Hawkins HK, Sorensen PH, Cowan DF. Desmoplastic small round cell tumor of the lung. Arch Pathol Lab Med. 2002;126:1226-8.

3. Altal OF, Aleshawi AJ, Tashtush NA, Alhowary A. A 23-year-old Joradanian woman with a desmoplastic small round cell tumor involving the ovary. Am J Case Rep. 2019;20:1675-8.

4. Su MC, Jeng YM, Chu YC. Desmoplastic small round cell tumor of the kidney. Am J Surg Pathol. 2004;28:1379-83.

5. Eaton SH, Cendron MA. Primary desmoplastic small round cell tumor of the kidney in a 7-year-old girl. J Pediatr Urol. 2006;2:52-4.

6. Egloff AM, Lee EY, Dillon JE, Callahan MJ. Desmoplastic small round cell tumor of the kidney in a pediatric patient: sonographic and multiphase CT findings. AJR Am J Roentgenol. 2005;185:1347-9.

7. Wang LL, Perlman EJ, Vujanic GM, et al. Desmoplastic small round cell tumor of the kidney in childhood. Am J Surg Pathol. 2007;3:576-84.

8. Collardeau-Frachon $S$, Ranchère-Vince $D$, Delattre $\mathrm{O}$, et al. Primary desmoplastic small round cell tumor of the kidney: a case report in a 14year-old girl with molecular confirmation. Pediatr Dev Pathol. 2007;10:320-4.

9. da Silva RC, Medeiros Filho P, Chioato L, Silva TR, Ribeiro SM, Bacchi CE. Desmoplastic small round cell tumor of the kidney mimicking Wilms tumor: a case report and review of the literature. Appl Immunohistochem Mol Morphol. 2009;17:557-62.

10. Rao P, Tamboli P, Fillman EP, Meis JM. Primary intra-renal desmoplastic small round cell tumor: expanding the histologic spectrum, with special emphasis on the differential diagnostic considerations. Pathol Res Pract. 2014;210:1130-3.

11. Eklund MJ, Cundiff C, Shehata BM, Alazraki AL. Desmoplastic small round cell tumor of the kidney with unusual imaging features. Clin Imaging. 2015; 39:904-7.

12. Walton WJ, Flores RR. Desmoplastic small round cell tumor of the kidney: AIRP best cases in radiologic-pathologic correlation. Radiographics. 2016;36:1533-8.

13. Janssens E, Desprechins B, Ernst C, De Smet K, De Mey J. Desmoplastic small round cell tumor of the kidney. JBR-BTR. 2009;92:60.

14. Sawyer JR, Tryka AF, Lewis JM. A novel reciprocal chromosome translocation $\mathrm{t}(11 ; 22)(\mathrm{p} 13 ; q 12)$ in an intraabdominal desmoplastic small round-cell tumor. Am J Surg Pathol. 1992;16:411-6.

15. Ladanyi M, Gerald W. Fusion of the EWS and WT1 genes in the desmoplastic small round cell tumor. Cancer Res. 1994;54:2837-40.

16. Gerald WL, Rosai J, Ladanyi M. Characterization of the genomic breakpoint and chimeric transcripts in the EWS-WT1 gene fusion of desmoplastic small round cell tumor. Proc Natl Acad Sci U S A. 1995:92:1028-32.

17. Furman J, Murphy WM, Wajsman Z, Berry AD 3rd. Urogenital involvement by desmoplastic small round-cell tumor. J Urol. 1997;158:1506-9.

18. Arnold MA, Schoenfield L, Limketkai BN, Arnold CA. Diagnostic pitfalls of differentiating desmoplastic small round cell tumor (DSRCT) from Wilms tumor (WT): overlapping morphologic and immunohistochemical features. Am J Surg Pathol. 2014;38:1220-6.

19. Ueno-Yokohata H, Okita H, Nakasato K, et al. Consistent in-frame internal tandem duplications of BCOR characterize clear cell sarcoma of the kidney. Nat Genet. 2015:47:861-3.

20. Khan MZ, Akhtar N, Hassan U, Mushtaq S. Diagnostic utility of BCOR antibody in clear cell sarcomas of kidney. Int J Surg Pathol. 2020;28:477-81.

21. Katz RL, Quezado M, Senderowicz AM, Villalba L, Laskin WB, Tsokos M. An intra-abdominal small round cell neoplasm with features of primitive neuroectodermal and desmoplastic round cell tumor and a EWS/FLI-1 fusion transcript. Hum Pathol. 1997:28:502-9.

22. Ordi J, de Alava E, Torné A, et al. Intraabdominal desmoplastic small round cell tumor with EWS/ERG fusion transcript. Am J Surg Pathol. 1998;22:1026-32.

\section{Publisher's Note}

Springer Nature remains neutral with regard to jurisdictional claims in published maps and institutional affiliations.

\section{Ready to submit your research? Choose BMC and benefit from:}

- fast, convenient online submission

- thorough peer review by experienced researchers in your field

- rapid publication on acceptance

- support for research data, including large and complex data types

- gold Open Access which fosters wider collaboration and increased citations

- maximum visibility for your research: over $100 \mathrm{M}$ website views per year

At BMC, research is always in progress.

Learn more biomedcentral.com/submission 